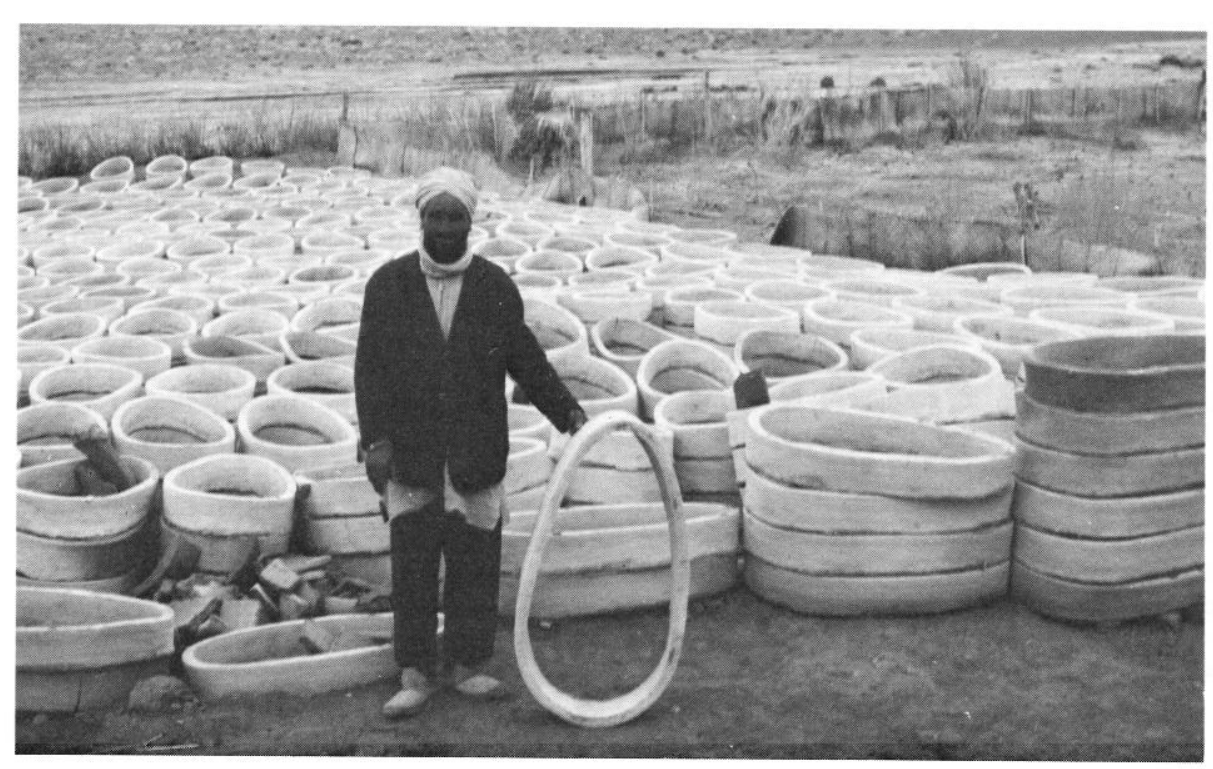

Fig. 2. Sun baked clay collars used to line sandy parts of the qanat tunnel at Estahard. These indicate the size of the shaft.

\title{
Qanats in the Old World: Horizontal Wells in the New
}

\section{KENNETH PEARSE}

Highlight: Horizontal wells make use of the principle of the qanat developed in Persia about 2,500 years ago and still widely used there and in other arid regions of the world. The driven horizontal well offers several important advantages over the hand dug qanat especially for livestock watering places.

Horizontal wells as a source of livestock water are a recent development in the southwestern United States (Welchert and Freeman, 1973). They should have an important place on arid and semiarid ranges throughout the western part of North America and elsewhere.

The basic concept of the horizontal well or qanat originated in Persia some 2,500 years ago. The expansion of the Persian Empire, beginning in the fifth centruy B.C., carried the idea from the Indus to the Nile and into Afganistan and China. Then the Islamic conquest extended the qanat to Cyprus, West Africa, Spain, and the Canary Islands. Similar structures are found in Mexico, Peru, and Chile, perhaps brought by the Spaniards, but perhaps an independent discovery by pre-Columbian New World people.

The author is a consultant, 634-D Avenida Sevilla, Laguna Hills, California.

Manuscript received December 1, 1972 .
Numerous publications have described the origin, development, spread, construction, and use of "qanats," "karez," "foggaras," or "galerias" as they are variously

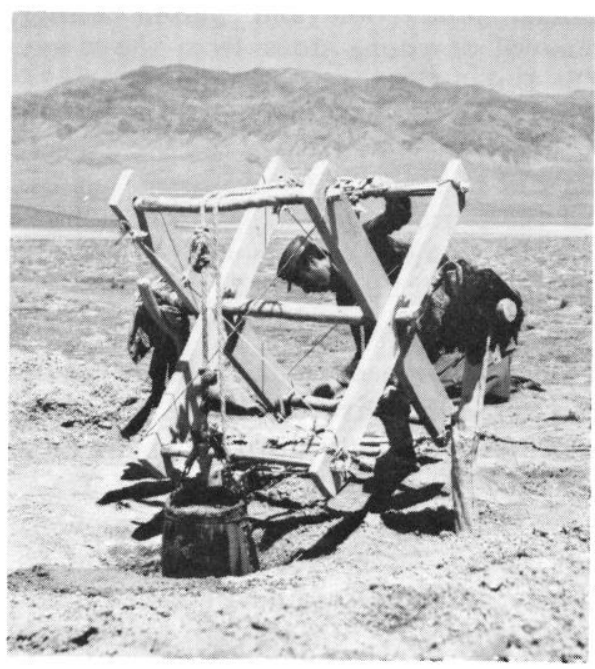

Fig. 1. Method of digging mother well and cleaning qanats at Estahard, Iran. called in different parts of the old and new worlds. These have been well summarized by English (1968).

In Persia qanats made possible and served as the basis for agricultural and livestock development and even now constitute the most important source of water supply for most rural as well as metropolitan areas in modern Iran. From one third to one half of the irrigated area of the country is watered by qanats, and most of the major cities rely on qanats for domestic water.

Qanats are ingeniously but laboriously constructed by hand digging. The site selected is usually an alluvial fan near the top of which a mother well is dug to the water table (Fig. 1). Then a tunnel, large enough to admit a man, is dug from the lower end of the fan so as to connect with the mother well on a very gentle slope. Where the tunnel passes through sand, sunbaked clay collars are used to form a lining (Fig. 2). Vertical shafts are constructed at intervals of 50 to 100 meters to provide ventilation for the workers, dispose of spoil, and provide access for maintenance (Fig. 3, 4). This results in a chain of spoil piles stretching across the arid slopes that is especially striking when viewed from the air. Some 


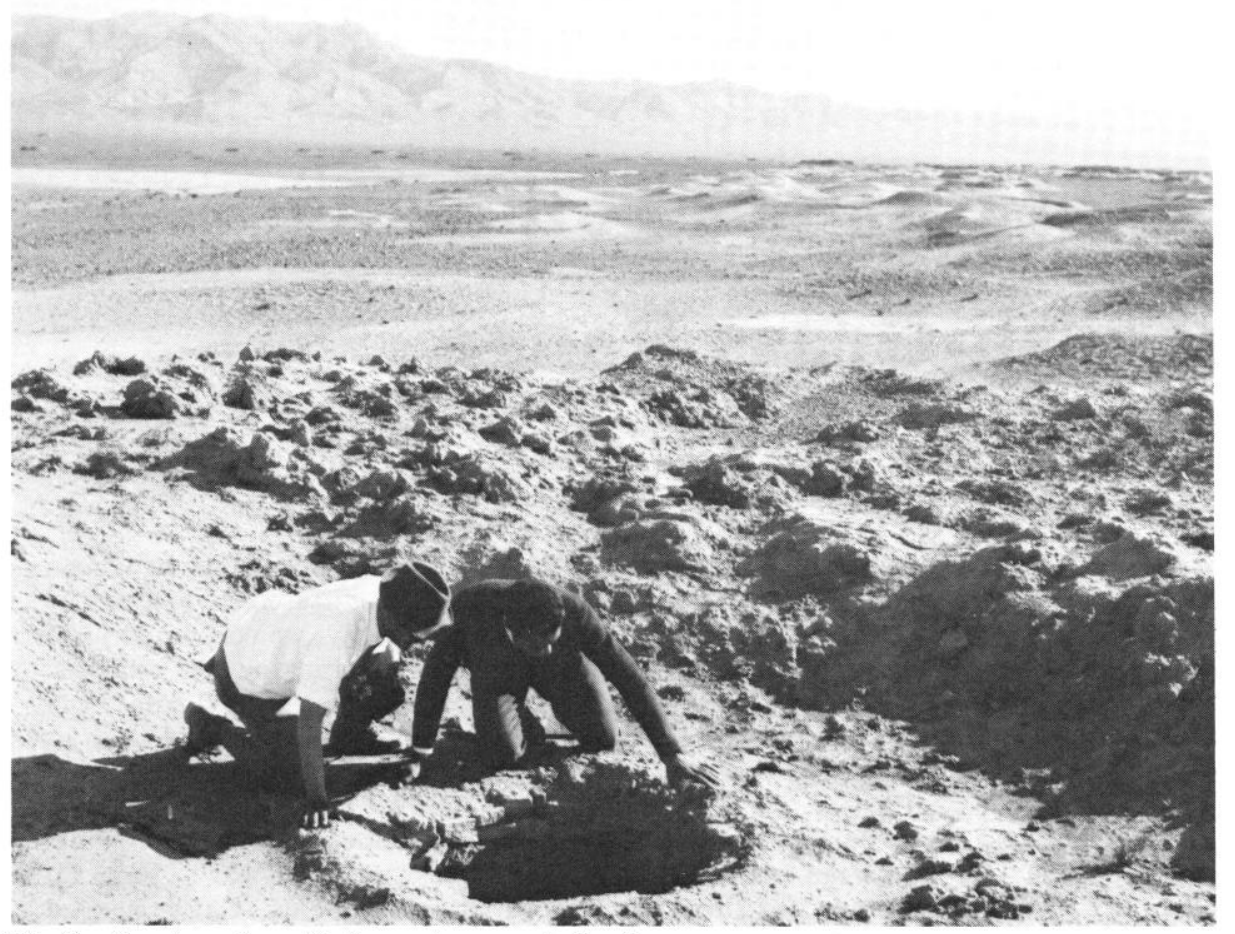

Fig. 3. Opening of ventilation and access shaft of a qanat at Estahard. Other shafts are indicated by spoil piles in the background.

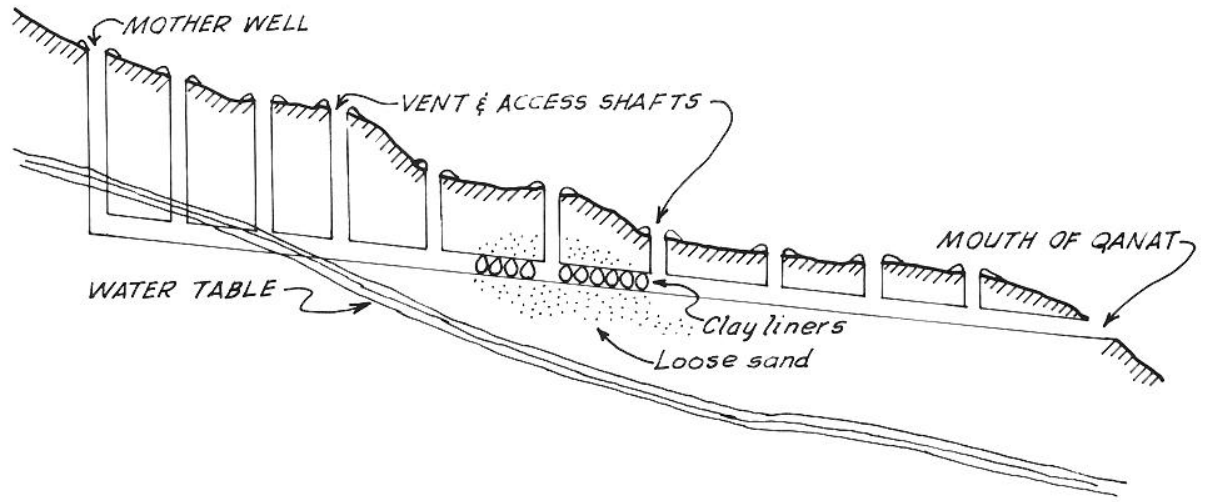

Fig. 4. Schematic cross section of alluvial fan showing construction of a typical qanat.

qanats extend for only a few kilometers but the length of many exceeds ten kilometers and some exceed 50 kilometers. The depth of the mother well is usually at least 50 meters and in some qanats is more than 300 meters.

Qanats are expensive to build. Skilled workers are required and the work is hazardous. The average cost is probably more than $\$ 10,000$ per kilometer, but where much sand is encountered and lining is necessary much greater expenditures are made. Annual maintenance is also expensive, and extensive repairs are frequently made necessary by floods, earthquakes, and other major disasters. Another serious drawback of qanats is their inefficient use and waste of water. Although they do not seriously lower the water table, the flow is more or less constant throughout the year, and during the nonirrigating season tremendous quantities of water go unused.

Deep wells are being driven throughout the area where qanats have been important. Cost of development and maintenance are less and the rate of withdrawal can be controlled. However, deep wells almost always significantly lower the water table, and this can and does have serious social, economic, and political repercussions. The cost of pumping, which is nil in the case of qanats, is considerable.

Horizontal wells as described by Welchert and Freeman (1973) seem to offer opportunities to overcome the shortcomings and to retain the advantages of qanats. There are doubtless many situations throughout arid and semiarid regions where driven horizontal wells are adapted. Their location will be somewhat limited by the terrain and the nature of the water table, and the horizontal drilling method of construction may make it impractical to achieve the lengths as well as water yields of hand dug qanats. These limitations should have little effect on their value for livestock water. Stockmen and land administering agencies should give serious consideration to making more use of them.

\section{Literature Cited}

English, Paul Ward. 1968. The origin and spread of qanats in the Old World. Proc. Amer. Philosophical Soc. 112;170-181.

Welchert, W. T., and Barry N. Freeman. 1973. Horizontal wells. J. Range Manage. 26:253-260.

\section{CLYDE ROBIN NATIVE SEEDS}

Castro Valley, California 94546 